International Migration, vol. 35, issue 3, page 99-124.

\title{
Assessing Emigrant Participation in Home Country Elections: The Case of Mexico's 2006 Presidential Election
}

Jean-Michel Lafleur* and Leticia Calderon Chelius ${ }^{\star * 1}$

\begin{abstract}
How did Mexican migrants react to the opportunity to formally partici- pate for the first time in home country politics during the 2006 Presidential Election? In this paper, we attempt to explain the low level of migrant voter registration in home country elections. Grounding ourselves on the existing literature on voter turnout, we verify two hypotheses that focus (1) on the role of Mexican authorities, and (2) on the interest of migrants and migrant associations in home country politics. Building on the case of Mexico, the paper concludes with proposing a series of variables upon which we suggest research could focus in order to assess migrant voter turnout in home country elections.
\end{abstract}

\section{INTRODUCTION}

$\mathrm{Si}$, se puede! Repeating continuously that Mexico had to implement external voting legislation, supporters of the emigrant vote were eventu- ally heard by the Mexican Parliament in 2005, when it adopted a law permitting them to participate in the Mexican Presidential Election from abroad. When the legislation granting the emigrant vote passed, sup- porters of external voting quickly realized after the initial celebrations that their dream of the massive participation of the 12 million Mexican citizens residing abroad would not materialize.1 However, no one would [END PAGE 99] anticipate that only 33,000 emigrants would eventually cast their vote

from abroad in the 2006 presidential election

Following this first experiment of external voting in Mexico, a debate began between emigrant activists and Mexican authorities on the rea- sons for such a low turnout. While external voting supporters were criti- cal of the bureaucratic registration procedures required for emigrant voting, electoral authorities in Mexico expressed their satisfaction with the reliability of the external electoral process and contended that low voter participation was due largely to emigrants' lack of interest in home country politics, more than any other factor.

Existing literature on voter turnout identifies a series of socio-economic, political and institutional variables that explain voter turnout in general (Geys, 2006). In addition, the literature on voting behaviour of minorities has helped understanding why migrants do or don't vote in host country elections. But are there also specific variables that explain migrant voter turnout in home country elections? Because of the absence of specific lit- erature on the topic, this paper uses the abovementioned literature and the small but rapidly growing literature on external voting to determine alternative explanations to low turnout among Mexican emigrant voters.

In the subsequent part of the paper, we move to a thorough analysis of the Mexican emigrant participation data in the 2006 election. Using this data and interviews conducted with emigrant leaders and government officials, we then test the two hypotheses on (1) the role of bureaucratic rules in the organization of elections abroad, and (2) the interest of migrants and migrant organizations in home country politics. The paper concludes by discussing how the case of

1 * Center for Ethnic and Migration Studies of the University of Liege, Belgium. ** Adscrita al Area de Sociologıa Política y Economica, Instituto de Investigaciones Dr. Jose Marí a Luis Mora, Mexico. 
Mexico helps to identify certain explanatory variables that could be applied to the analysis of other cases.

\section{EXPLAINING MIGRANT VOTER TURNOUT IN HOME COUNTRY ELECTIONS: VIEWS FROM EXISTING LITERATURE}

Explaining voter turnout has long been a preoccupation of political sci- entists. Based on an extensive review of empirical research on the topic, Geys (2006) identifies three kinds of variables that are most frequently used in literature to explain turnout: The first set of variables is of polit- ical nature. Under this category, campaign spending, closeness of the election, and political fragmentation (i.e., the number of parties partici- pating in the election) are examined as factors influencing turnout.

[END PAGE 100]

Institutional variables are the second set of variables that are usually observed, which focus on the role of concurrent elections, the electoral system (i.e., the mode of attribution of seats), and of registration requirements which impact voters' participation. As we will see below, registration requirements deserve great attention in discussions on exter- nal voting. Under a third category in which he unconvincingly lists socio-economic variables Geys stresses diverse elements such as the size of the voter constituency, the duration of residence in a specific constitu- ency, and previous participation (because voting may be habit-forming) as frequently examined factors. In addition to these variables that apply to all voters, are there demo- graphic and socio-economic variables that apply particularly to emigrant voters participating in home country elections? Also, should some of the existing variables be refined for this specific form of electoral participa- tion? These questions can be answered by looking at other specialized bodies of literature. The literature on immigrant voting, which seeks to explain foreigners' or citizens of immigrant origin's turnout in host country elections, has refined the discussion on the influence of socioeconomic factors on minorities' turnout. As Bevelander and Pendakur (2009) show in their review of this literature, different approaches predominate in Europe and North Amer- ica with respect to the relevance of socio-economic variables for immi- grant voter turnout. In North America, Bevelander and Pendakur (2009) postulate that research has focused on the relation between human capital and voting so far. Research thus focuses on demographic and socio- economic variables (age, education, occupation) as factors explaining lower turnout among minorities (Tuckel and Maisel, 1994; DeSipio, 1996). In Europe, where several countries allow foreigners to take part in local elections, an important number of studies follows Fennema and Tillie's work (1999) on social capital. According to these two scholars, greater involvement of migrants in ethnic associations (used to measure levels of social capital), leads to greater trust in host country institutions. Higher levels of trust in institutions, in turn, lead to higher voter turnout. Applied to different migrant communities in Europe, this assertion has been consistently confirmed (Berger et al., 2004; Jacobs et al., 2004; Togeby, 2004).

In the case of external voting, trust must be envisaged with respect to home country institutions and how it affects migrants' involvement in home country politics. As literature on migrants' involvement in [END PAGE 101]

conflicts has examined, distrust in home country institutions may strongly stimulate migrants' desire to get involved in home country affairs and lead to more radical political positions (Turner, 2008). How- ever, as the case of Mexico demonstrated until the 1980s, distrust may also lead migrants to refuse to formally participate in home country pol- itics because elections are widely considered unreliable or illegitimate. Beyond the issue of trust in home country institutions, the general issue of emigrants' interest in home country politics and elections, in particu- lar, deserves to be discussed. In another article (Lafleur, forthcoming), we examine a frequent argument used by opponents of external voting that emigrants are not interested in home country elections because they do not live there anymore and accordingly do not feel concerned by 
political decisions taken there. In other words, distance from emigrants' country of origin leads to lower levels of interest in home country poli- tics, translating into low emigrant voter turnout. We believe that this hypothesis needs to be discussed on two different levels. First, migrants' interest in home country elections must be exam- ined at the individual level to determine whether interest and turnout are strongly connected. Second, interest must be measured through migrant associations' involvement in informing migrants about home country elections. In comparison to host country elections, the monetary and time costs of accessing information on home country elections is indeed much higher for citizens abroad. The difficulty of the consular network to reach citizens abroad and the local media's lack of interest (partly compensated for by ethnic media and easy electronic access to home country media) stand out as main reasons. Because of these particular environmental difficulties which make information on home country elections less accessible, we hypothesize that the active involve- ment of ethnic associations in informing migrants about elections and the registration procedures has an impact on voter turnout. The second variable that we hypothesize as specific to external voting is based on results from our analysis of existing external voting literature. Despite the fact that some countries have employed external voting legisla- tion for decades, literature on the topic has only developed in recent years. This literature does not, however, address the issue of voter turnout in home country elections, but approaches external voting from three differ- ent perspectives. First, there are works that seek to define the practice and document its development (Caldero' n Chelius, 2003; Collyer and Vathi, 2007; IDEA, 2007; Nohlen and Grotz, 2000) by which we learn that the number of countries allowing external voting has boomed in recent years

[END PAGE 1012

and that, despite the limitations in many countries' legislations, it has become the norm at the international level. This body of literature is com- plemented by a series of case-specific studies that underline the evolu- tion of the external voting issue in individual countries, mainly in Latin America (Escobar, 2007; Itzigsohn, 2000; Martí nez Saldañ a, 1998). Sec- ond, a different wave of scholars have discussed the development of exter- nal voting from a normative viewpoint by linking it to the development of other state policies aimed at reaching out to citizens abroad (Barry, 2006; Baubo" ck, 2007; Lo' pez-Guerra, 2005; Rubio-Marí n, 2006; Spiro, 2006). Third, and most importantly for the purpose of this paper, a series of researchers have tried to explain the global trend that pushes states to grant voting rights to their citizens abroad sometimes in joint analysis with the development of dual citizenship worldwide (Lafleur, 2009; Lafleur, forthcoming; Levitt and de la Dehesa, 2003; Rhodes and Harutyunyan, 2010; Waterbury, 2010; Wucker, 2004). This literature underlines the role of different variables such as the democratization of emigrant-sending states, their dependence on remittances, and emigrant lobbying. One of such variables that we have identified in previous works (Lafleur, 2009; Lafleur, forthcoming) is the role of government agencies and political parties in the adoption of external voting legisla- tion. Government agencies (such as Foreign Affairs ministries) may indeed be very reluctant to implement external voting legislation because of organizational burdens. Most importantly, we argue, external voting legislation results largely from negotiations between political parties that see potential electoral benefits from it and others that fear the negative impact of emigrants on overall electoral results. Accordingly, parties that oppose or fear the implementation of external voting will push to limit its impact on overall results. One way of limiting the impact of that vote is by introducing different bureaucratic barriers to the exercise of the right to vote from abroad in the legislation. The literature on voter turnout examined above have already underscored the influence of registration procedures on voter turnout. Here, however, we go further by hypothesizing that some states may voluntarily set up bureaucratic barriers in their external voting legislation to ensure that turnout is low, thus limiting the overall impact of emigrants' votes (see Table 1).

\section{THE 2006 MEXICAN PRESIDENTIAL ELECTIONS: THE DATA}

Before we examine the two hypotheses we developed above, we find it necessary to establish 
the numerical importance and the profile of the [END PAGE 103]

NUMBER OF VALID REQUESTS TO BE ADDED TO THE EMIGRANTS' ELECTORAL LIST BY COUNTRY OF RESIDENCE5

TABLE 1

NUMBER OF VALID REQUESTS TO BE ADDED TO THE EMIGRANTS' ELECTORAL LIST BY COUNTRY OF RESIDENCE ${ }^{5}$

\begin{tabular}{|r|lrr|}
\hline & Country of residence & Number of requests & Total Mexican population* \\
\hline 1 & United States & 35,763 & $11,500,000$ \\
2 & Spain & 1,238 & 21,107 \\
3 & Canada & 863 & 49,925 \\
4 & France & 510 & 1,393 \\
5 & United Kingdom & 447 & 5,297 \\
6 & Germany & 393 & 9,225 \\
7 & Italy & 212 & 6,798 \\
8 & Switzerland & 188 & 751 \\
9 & Netherlands & 100 & 3,000 \\
10 & Belgium & 83 & 1,338 \\
\hline
\end{tabular}

* Including citizens younger than 18 years old.

* Including citizens younger than 18 years old.

few emigrants who participated in the 2006 Mexican Presidential Elec- tions. In doing so, we oppose the various estimations of voter turnout that were produced before the elections to the actual registration figures as published by the Federal Electoral Institute's (IFE) unit in charge of external voting (COVE).

During the preparation of the external electoral process in 2006, several experts warned that the rate of participation abroad was likely to be limited. An expert commission of the IFE set up in 1998 to study exter- nal voting in Mexico estimated that around 11 million Mexicans residing abroad could be of voting age for the 2000 election but that only 1.5 million had a valid voter identity card. Later, in a technical opinion addressed to Parliament in 2005, the IFE estimated that 4 million Mexi- cans in the United States held a voting identity card, but warned that different factors would reduce the actual participation (IFE, 2005). Marcelli and Cornelius (2005) attempted to develop estimations based on a survey of the Mexican migrants in Los Angeles who returned to Mexico to participate in the 2000 elections and came up with a potential participation of 125,000 to 360,000 emigrants. For some migrants and migrant associations, particularly the Coalition for the Political Rights of Mexicans Abroad (CDPME), it was also clear that not all of the 4 million emigrants said to hold a voting identity card would actually reg-ister to vote. The CDPME nonetheless expected that the associations' and the IFE's joint effort in promoting registration would result in over 10 percent of them actually participating (Ross Pineda, 2005). [END PAGE 104]

TABLE 2

REGIONAL STATE OF ORIGIN OF EMIGRANTS WHO REQUESTED REGISTRATION AS VOTERS6 
TABLE 2

REGIONAL STATE OF ORIGIN OF EMIGRANTS WHO REQUESTED REGISTRATION AS VOTERS $^{6}$

\begin{tabular}{|r|lc|}
\hline & Region of origin & Number of requests \\
\hline 1 & Federal District & 6,281 \\
2 & Jalisco & 5,047 \\
3 & State of Mexico & 4,149 \\
4 & Michoacán & 3,368 \\
5 & Guanajuato & 2,793 \\
6 & Nuevo Leon & 1,799 \\
7 & Puebla & 1,631 \\
8 & Baja California Norte & 1,582 \\
9 & Chihuahua & 1,235 \\
10 & Veracruz & 1,191 \\
11 & Others & 11,800 \\
\hline
\end{tabular}

In reality, all these estimations far exceeded the real registration statis- tics. As emigrants had to apply to the IFE to be added to the voters' list, the IFE received 57,312 emigrants' application forms of which 40,876 actually fit the criteria. Once added to the list, the emigrant vot- ers would receive a ballot and return it to the IFE by mail. Eventually, 81 per cent of these eligible voters $(32,632)$ cast their votes in the 2006 presidential election. One further element that is striking is that while Mexicans residing in the United States represent 98 per cent of the Mex-ican emigrant population, they only accounted for 85.61 per cent of the votes cast in the 2006 presidential election. Higher registration rates were thus observed among Mexicans migrants living outside of the Uni- ted States.

Looking at the regional origin of registered emigrants, Table 2 shows that a majority comes from the Federal district and that more than half of them come from just 5 of the 32 Mexican states. It may appear surprising that traditional migrant-sending states like Zacatecas have not performed better in terms of registration, especially when they are known for the dynamism of their transnational associations and for the authorities' support to transnational political participation at the local level (Moctezuma Longoria, 2003).

The elections results abroad appear quite different from overall election results, as shown in Table 3. Naturally, the representative character of the 33,111 voters who participated in the external voting process is ques- tionable due to the likely selection bias introduced by the law as we [END PAGE 105]

TABLE 3

ELECTORAL PREFERENCES OF EMIGRANTS FOR THE 2006 PRESIDENTIAL ELECTION7 
TABLE 3

ELECTORAL PREFERENCES OF EMIGRANTS FOR THE 2006 PRESIDENTIAL ELECTION $^{7}$

\begin{tabular}{|c|c|c|c|}
\hline Party & $\begin{array}{l}\text { Election results } \\
\text { among emigrants }\end{array}$ & $\begin{array}{l}\text { Electoral preferences } \\
\text { among migrants as } \\
\text { observed by } \\
\text { Cornelius et al. } 2007\end{array}$ & $\begin{array}{l}\text { Overall results } \\
\text { of the } 2006 \\
\text { Election }\end{array}$ \\
\hline PAN & $58,29 \%$ & $37 \%$ & $35,89 \%$ \\
\hline $\begin{array}{l}\text { Alianza por el } \\
\text { bien de todos (PRD) }\end{array}$ & $34,00 \%$ & $34 \%$ & $35,31 \%$ \\
\hline PRI & $4,17 \%$ & $21 \%$ & $22,26 \%$ \\
\hline
\end{tabular}

examine below (Smith, 2008). Nonetheless, the limited experiment con- firmed the trend that Mexican scholars observed during the 2000 elec- tions, when special polling stations were set up in Mexican border towns to allow a very limited number migrants and non-migrants finding themselves outside of their electoral district on the day of the elections to cast their vote (Espinoza Valle, 2004):2 strong performances of the left-wing Partido de la Revolucion Democratica (PRD) and especially the liberal party Partido Accion Nacional (PAN), while the former party-state Partido Revolucionario Institucional (PRI) was far less popular with emi- grants than with those citizens residing on the national territory. As opposed to these observations, the survey conducted among more than 1000 Mexicans in Dallas, San Diego and Indiana by McCann, Cornelius and Leal (2006) confirms the selection bias in the emigrant voting popu- lation. Indeed, their sample, which included voters and non voters, showed similar political preferences to those shown by the whole Mexi- can population at the 2006 election therefore supporting the idea that the 33,000 emigrant voters might not be representative of the whole emi- grant population.

\section{WHY WAS PARTICIPATION SO LOW? THE BUREAUCRATIC BARRIER HYPOTHESIS}

On June 28, 2005, Mexico's House passed long-awaited legislation on external voting. That legislation, however, resembled more a last-minute political compromise than a thorough measure to enfranchise the mil- lions of citizens abroad. After President Fox promised in 2000 to imple- ment external voting before the end of his term, political parties were pressured to take a stance on external voting, but were hesitant to do so [END PAGE 106]

for various reasons. On the one hand, emigrant associations had prom- ised to mobilize their relatives in Mexico to cease supporting the parties that would oppose external voting. On the other hand, the unknown impact of the potential millions of emigrant voters on overall elections results created uncertainty for all political parties who were resultantly reluctant to legislate. To break this deadlock, President Fox asked his Undersecretary of Political Development to facilitate an agreement on the principle of external voting and the modalities of its application that would satisfy all major political parties. That agreement, signed on 6 April 2004, con- tained the major principles that would later guide the passage of formal legislation on 28 June 2005. This law provided for the organization of elections abroad, while ultimately limiting the impact of the emigrant vote: external voting would only be allowed for presidential elections, the Federal Electoral Institute (not the consular network) would be in charge of electoral operations abroad, and voter identity cards would be required to vote but would not be delivered abroad.

This law's greatest restrictions are contained within Article 275, which requires emigrants to register by completing a form and returning it to the IFE in Mexico with a copy of their voter 
identity card. Because these cards were not delivered abroad, only those emigrants already holding such cards or willing to travel to Mexico to obtain one would be eligible to vote. For the others - the undocumented migrants unable to travel back and forth, those who had misplaced their voter identity card (or who had thrown it away when crossing the border), and those who left Mexico before such a card was issued - possessing this indispensable voting card would be difficult and time-consuming, if not entirely impossible.

Further, this law obliged emigrants to download and print the registra- tion form from the internet, then complete it and send it back to Mexico with a copy of their voter identity card and proof of residence abroad (such as a utility bill) by registered mail. Several migrant associations have noted that the cost of postage (usually US\$ 8), and the time and energy required (going to a post office during work hours and speaking to a post office official in English) were strong disincentives for the many marginalized migrants. It is also important to note that this proce- dure discouraged less-educated emigrants to complete their external vot- ing applications, as it required them to have internet access and knowledge, as well as a certain level of literacy skill in order to complete the form (Caldero' $n$ Chelius, 2007; Smith, 2008). [END PAGE 107]

With regard to the actual implementation of the law, the IFE had been put in a difficult position by Mexican legislators. The law required that voter registration forms be returned to the IFE between 1 October 2005 and 15 January 2006 (while registration activities also be suspended in December). Considering that the law had only been approved in the end of June 2005, and that the IFE only had three months for administrative preparation for its implementation (such as creating the registration form) and setting up an information campaign for citizens abroad, the time-frame to inform the emigrants of their new right, and to provide them adequate time to fulfil all registration requirements was relatively short (Caldero' n Chelius, 2010).

Some migrant associations soon realized that registration was surely going to be limited, and accused the IFE of deliberately implementing the law in a restrictive fashion to make it difficult for emigrants to regis- ter to vote. Their criticism focused on two main issues. First, the regis- tration procedures outlined by the IFE was very complex, which discouraged migrants to complete them, and led many others to do so improperly, resulting in their applications' invalidity Indeed, out of the 54,866 forms received by the IFE on time, only 40,876 were eventually approved. Around 25 per cent of potential emigrant voters were rejected for technical reasons, such as filling out the form incorrectly, or by send- ing the form by regular mail instead of registered mail. Second, migrant associations criticized the IFE for insufficiently informing citizens abroad of their new rights during the registration campaign. Disappoint- ment and frustration were commonly shared feelings among emigrant leaders in the United States. A former councilman of the Institute for Mexicans Abroad (IME) who we interviewed, described the IFE person- nel promoting the vote as "mere bureaucrats that received a lot of money to come over and do nothing in the United States [...] They did not do what they had to do. They did not do the publicity they had to do like they do in Mexico."

On the IFE's side, as underscored in the interview below with a civil ser- vant affiliated with the Coordination for the Vote of Mexicans Residing Abroad (COVE), a department of the IFE, the agency thoroughly ful- filled its legal obligations, and was even proactive to secure maximum emigrant voter registration within the limits of the legislation and allo- cated budget:

More or less when the electoral process began abroad and we started to see that the [registration] figures on the first days were terribly low

[END PAGE 108]

(...) all the red lights started to flash at the Institute, and one of the first strategies that we deployed was to ask for the help of some [migrant] associations. Then, the only thing we had to be careful about was that no associations related to political parties got involved.

The IFE's stated institutional priorities were to safeguard the reliability and the validity of the electoral process, encourage citizens to vote, and ensure that their rights and obligation were respected. Following these principles, the IFE would consider the first experience of external voting successful if the elections were fair and voter turnout was high. But, as rightly underscored by Smith (2008), the IFE's was required to fulfil cer- tain obligations that were contradictory to its 
stated mission. Indeed, with the prohibition for political parties to campaign and raise funds abroad, the IFE not only had to administratively organize elections abroad, but also to circulate informative materials on each major politi- cal party. Providing party information contradicts the principle of objec- tivity grounding the IFE's establishment - to ensure that the actors involved in organizing the election were not involved in political campaigns.

As we have seen in this section, the Mexican legislators have adopted a very bureaucratic external voting system that gave important missions to the IFE and little time to fulfil them. But, is this enough to explain low participation among Mexicans abroad? Even the most conservative participations estimates we reviewed at the beginning of this article men- tioned a possible participation of 125,000 migrants. Less than half this figure has actually formally tried to register. This lead us to examine a second hypothesis to explain low participation stating that a share of the Mexican population abroad has no interest in voting in home coun- try elections.

WHY WAS PARTICIPATION SO LOW? THE MIGRANT'S DISINTEREST HYPOTHESIS

A common argument used by opponents to external voting to justify their position is often that emigrants are not interested in taking part in home country politics because they have left the country and thus no longer feel affected by home country politics. We have also underlined the difficulties of using this variable for two reasons: First, interest in home country politics can be coupled with distrust in institutions which undermine turnout. Second, as we have just seen, the complexity of

[END PAGE 109]

registration procedures abroad and the difficulty to access information may prevent interested citizens residing abroad from registering as vot- ers. Yet, in the case of Mexico and other countries, it can also be argued that emigrant associations have a potentially significant impact on voter turnout abroad. As the state exhibits a weaker capacity to inform and register voters abroad than within national territory, the mobilization of emigrant associations could complement state efforts in registering vot- ers. For this reason, we believe it is relevant to measure interest in home country elections both on the individual and association level.

Individual interest for home country elections

When migrants cross the border, do they stop caring about their home country politics? Different surveys held before the July 2006 Presidential Election help us identify the interest of emigrants in Mexican politics and its impact on voter turnout.

A first quantitative contribution to the debate is that of the Pew His- panic Centre that surveyed almost 1000 Mexicans residing in the United States just after the end of the registration period (Suro and Escobar, 2006). The most striking element of the survey is certainly the lack of knowledge that Mexicans abroad have of the electoral process in their home country. Indeed, while only 45 per cent of the respondents knew that the Presidential election was taking place in 2006, 78 per cent knew that Mexicans abroad would be invited to vote at the next election. Yet, this latter figure cannot be interpreted as a result of IFE's promotional effort, for only 36 per cent of the interviewees knew that the deadline had already passed. The 925 respondents who did not register were sub- sequently proposed five reasons to explain this situation. While the lack of documents $(67 \%)$, the lack of information on the procedure $(55 \%)$ and the difficulty of the procedure $(46 \%)$ were retained as explanations, only 2 per cent of the respondents expressed that they had no interest in Mexican politics because their life was now in the United States. The question of the Mexican migrants' interest in home country politics has also been specifically measured by McCann et al.'s survey (2006) among more than 1000 emigrants in three US cities between February and June of 2006. Results show that between 8 and 12 per cent of the Mexican adult population in the United States followed a great deal the 2006 presidential campaign, while between 10 and 19 per cent only somewhat followed it. Also, between 15 and 20 per cent of the respon- dents claimed to talk about Mexican politics with friends and family at [END PAGE 110]

least a few times a week. Despite the fact that the level of interest observed among non-migrant Mexicans is significantly higher, these scholars nonetheless conclude that Mexicans abroad have a "greater civic potential than the minuscule number of expatriates who cast a bal- lot would 
suggest."'(McCann et al., 2006)

Two further elements that confirm findings of the literature on voter turnout in general ought to be underlined: First, unsurprisingly, this sur- vey shows that interest in Mexican politics varies significantly according to levels of education. Second, emigrants who retained a clear party identification in Mexico were also most likely to have larger interest in the campaign. This last point is complemented by Waldinger and Lim's (2009) analysis of the Latino National Survey conducted in 2006 among 2,600 Mexicans migrants in the United States which confirms that there is a "habit effect" in political participation. In other words, emigrants who were engaged in Mexican politics prior to migration are more likely than others of being interested in Mexican politics and external voting after migration.

Looking at the results of these different surveys, it appears that a much larger number than the 33,000 external voters have a true interest in Mexican politics. Aside from the lack of voter identity cards, the diffi- culty to register, and the lack of information, which explain partial reg- istration figures, we must also understand that emigrants may not be ready to make much effort in the voting process abroad even though they may have an interest in doing so. This point is supported by the 1998 survey conducted by Mexican scholars that showed that $75 \%$ of the Mexican migrants were willing to spend a maximum of one hour to vote (Espinoza Valle, 2004). This data aligns itself with the fact that countries that have easy procedures to access external voting rights (such as Belgium or Italy) also have higher levels of participation. What this data also shows is that Mexican emigrants want to devote far less time to political participation in their home country than to other administrative procedures that have a direct impact on their daily lives. Indeed, as underlined by Waldinger (2008), millions of Mexicans in the United States have applied for a consular identification card since new security rules have made it increasingly difficult for undocumented migrants to make basic administrative acts in the United States (e.g., opening a bank account) without proper documentation. In this case, as opposed to registering to vote from abroad, the cost and the long lines to obtain the card have not deterred emigrants from applying. Unsur- prisingly, participating to home country elections is thus less of a [END PAGE 111] priority to citizens abroad than other administrative procedures with Mexican authorities that facilitate daily life in the country of residence. To conclude this analysis of emigrant interest in external voting at the individual level, surveys show that a larger portion of the emigrant pop- ulation than the 33,000 actual voters have a genuine interest in voting in home country elections. In addition to the bureaucratic barriers discussed above, this interest does not materialize in turnout for two main reasons: First, Mexicans abroad were uninformed of the registration process. Second, contrary to other administrative steps that have a direct impact on their daily life in their country of residence, migrants are ready to devote very little effort to registering, and are thus likely to give up very easily as they face bureaucratic barriers to exercise their right to vote. These two elements invite us to examine more closely the role of migrant associations in informing and helping migrants to regis- ter. The involvement of migrant associations in the registration campaign as a sign of (dis)interest Considering the long history of Mexican migration to the United States, it may appear surprising that migrant associations only started lobbying actively in favour of external voting in the 1980's. Mexicans abroad did not strongly demand external voting because the regime in place in Mexico rendered elections there "mere rituals" (Martí nez Saldaña, 1998). Since electoral processes were not transparent, emigrants did not feel the need to take part in electing institutions in which they had little trust. A migrant leader from Chicago we interviewed confirms that the process of democratic transition of the mid-1980's changed the situation and encouraged emigrants to lobby for the right to vote from abroad because they "(...) wanted to be part of what was happening in Mexico and (...) did not want to keep being second-class citizens".

Passed the celebrations of June 2005, when the legislation was adopted, many activists felt that massive participation would be impossible due to the restrictions of the law, but none envisioned that such a limited num- ber of emigrants would register. Unlike the IFE, migrant associations were less interested in the legality of the proceedings than in the inclu- sion of the largest 
possible number of migrant voters. This viewpoint is very clear in the interview of the following lobbyist for external voting that we interviewed and who originally defended the idea that external voting should take place in polling stations abroad:

[END PAGE 112]

(...) the idea is that the electoral process must turn into a civic celebra- tion (fiesta civica) abroad. (...) you go to the casa Zacatecas or Guanajuato or Michoaca' n or Guerrero [abroad] and you set up 10 poll- ing stations there. The people will come in an orderly manner because they all know each other. They will meet with their friends: they will see each other, they will feel part of Mexico in this small place.

Most Mexican associations took some time before realizing they could make a difference in helping citizens to register in the US. In an attempt to improve registration figures, the IFE hired two members of a migrant lobby group, the Coalition for the Political Rights of Mexicans Abroad (CDPME), as consultants to improve the promotion strategy. Obvi- ously, these persons had been chosen for their linkage to the commu- nity. One of them, a Chicago resident, confirmed during the interview that, even though his role officially consisted in advising the IFE on how to maximize its resources to promote registration abroad, he was also trying to influence the administrative decisions taken by the IFE which were impacting the registration process.

Aside from these consultants, most of the associative work was done at the grassroots level. A migrant activist from the Concilio Hispano in Chicago described the typical role played by clubs and federations during the interview: "We distributed almost 35,000 forms in the asso- ciations, the church clubs, the shops, at the street corners. (...) We also got involved in the registration process but in a secondary way because our intention was to promote it [the right to vote] as much as possible".

The other IFE consultant we interviewed believed that this strategy proved unsatisfactory due to the fact that emigrants who received the form on the street or at the church would be less likely to register once at home because of the complexity of the process (filling in the form, making a copy of the voting identity card, providing a proof of resi- dence, and sending it by registered mail). Conversely, those citizens who were attended personally (in shopping malls for instance) by other migrants accredited by the IFE to help them fill in the form on the spot (a strategy set up at the very end of the registration process) would be more likely to go through the whole process. This supports the idea that emigrant associations cannot only make a difference by informing citi- zens abroad of their right to vote, but they can help them overcome the bureaucratic registration procedure, which proves the most burdensome obstacle.

[END PAGE 113]

Other aspects of the registration data deserve discussion in our evalua- tion of associations, such as the regional origin of voters and their place of residence. How is it that the large sending regions of Zacatecas and Michoaca' $n$ have fewer emigrants registered than the Federal District, which is a much newer sending area? Zacatecas is a state that has invented the famous $2 \times 1$ matching fund programme, and has a long his- tory of transnational involvement of migrant organizations through clubs and federations. Also, it has been a pioneer in the representation of emigrants by creating the concept of "binational citizenship," which guarantees the presence of emigrants in the state legislature (Moctezuma Longoria, 2003). Michoaca' $n$ also counts numerous transnational associ- ations and has allowed emigrants to vote in Gubernatorial Elections only a few months after the 2006 Presidential election. Interviewees from the CDPME and IFE argue that the role of associa-tions proceeding from traditional sending regions must be questioned. The following CDPME leader residing in Michoaca' $\mathrm{n}$, for instance, is convinced that associations did not play their part:

[the associations] tell you that 'we represent 600,000 Michoacanos in the Middle-West' and, I would tell to one leader who was saying that, "listen, from those 600,000 that you represent, at least you could have registered one per cent'.

This situation leads us to make two observations: First, as underlined by our interviewee, clubs and federations of migrant associations, including those who actively lobbied for external voting, most likely did not manage to secure the participation of their own members who pos- sessed a voter identity card. This questions their ability to mobilize migrants for home country political 
issues. Second, traditional Mexican emigrant associations in the United States may not necessarily have the same focus on home country issues as the transnational hometown associations (HTA). HTA's, as underscored by Portes, Escobar and Radford (2007), are run by a minority of older, better-established, and more edu- cated emigrants. Also, while HTAs may be well-suited for co-develop- ment projects and lobbying at the local level, it remains doubtful that their small structures are appropriate for electoral mobilization.

Before we conclude this paper, we must also examine the place of resi- dence of the registered voters, and what it tells us about the relevance of the local context and the role of associations there. While Table 4 shows us that the repartition of voters according to the place of residence in [END PAGE 114]

TABLE 4

STATE OF RESIDENCE OF THE MEXICAN POPULATION IN THE US COMPARED TO THE STATE OF RESIDENCE OF REGISTERED VOTERS8

TABLE 4

STATE OF RESIDENCE OF THE MEXICAN POPULATION IN THE US COMPARED TO THE STATE OF RESIDENCE OF REGISTERED VOTERS ${ }^{8}$

\begin{tabular}{|l|cl|}
\hline $\begin{array}{l}\text { State of } \\
\text { residence }\end{array}$ & $\begin{array}{c}\text { \% of the total } \\
\text { Mexican population } \\
\text { in the US }\end{array}$ & $\begin{array}{l}\text { \% of the total } \\
\text { emigrant voting } \\
\text { population registered } \\
\text { in the US }\end{array}$ \\
\hline California & 37.3 & 37.22 \\
Texas & 21 & 15.81 \\
Illinois & 6.3 & 9.27 \\
Arizona & 5.4 & 3.93 \\
Georgia & 2.5 & 2.44 \\
Florida & 2.3 & 3.28 \\
\hline
\end{tabular}

the United States greatly corresponds to the repartition of the Mexican population on US territory, Table 2 shows a different story outside of the United States. Despite the weakness of their migrant associative net- work, Spain, France and Switzerland registered significantly higher proportions of their total Mexican population than the United States or Canada did. While we still lack extensive data to explain this situation, different hypothesis can help us understand this situation. There is a likely smaller share of undocumented migrants within the Mexican pop- ulation in Europe, which implies that relatively less potential voters were excluded for lack of voter ID card. There is then the hypothesis that the share of highly-skilled Mexican migrants is higher in Europe than in the United States. Considering the importance of educational attainment in turnout, this data could explain the higher turnout among the much smaller Mexican communities in Europe. Yet, our interview with the CDPME representative in Switzerland, who conducted a promotion campaign for the vote, also points to the role of associations and to the importance of the local context.

While the interviewee underscores the similar difficulties related to the complexity of the registration procedure and the short period to register, he also underscores how much easier it was for emigrants promoting the vote to reach potential voters despite the absence of IFE's campaign there. Considering the size of the country and the fact that only 751 Mexicans live in Switzerland (according to the Mexican consular regis- try), emigrant activists there were able to get in touch directly with vir- tually all of them to inform them about the registration procedure. Additionally, since the Latino media offering is substantially more lim- ited in Switzerland than in the United States, the 300 radio advertise- 
[END PAGE 115]

ments they paid on the Latino radio, and the airtime discussing Mexican politics and external voting, were also likely to have a much bigger impact in Switzerland than any similar campaign conducted in the Uni- ted States.

To conclude the analysis of this second hypothesis, we have seen that the different surveys prove it cannot be assumed that Mexicans abroad do not have an interest in home country politics. The reality of what we observed was that this very general interest does not translate to a readi- ness to make substantial effort to be able to exercise their right to vote from abroad. In this context in which voting in home country elections is a low priority compared to more pressing daily-life issues in the coun- try of residence, bureaucratic barriers to registration appear to be a strong deterrent to actual participation in home country elections.

By underscoring the limited capacities of Mexican authorities abroad in informing and registering potential voters (especially since the exten- sive Mexican consular network is prevented from getting involved in the process), we also underscored the potential impact of emigrant associations as promoters of external voting. However, several elements seemed to have limited the associations' impact on voter turnout: tardi- ness in getting involved in the registration campaign, lack of pressure to register with traditional associations by their members, the structural deficits of HTA's for electoral mobilization, and the difficulty to reach emigrants in large receiving countries that have multiple offerings of ethnic media.

\section{CONCLUSION: IDENTIFYING VARIABLES TO EXPLAIN EMIGRANT TURNOUT IN HOME COUNTRY ELECTIONS}

In this paper, we have focused on two specific variables that have been debated by policymakers and academics alike in Mexico to explain low turnout among emigrant voters concerning the 2006 Presidential elec- tions. As we conclude this paper, we wish to discuss how the Mexican case study helps us to identify variables to analyse turnout among emi- grants in Mexico and beyond. To do so, we will start with the typology of variables made by Geys (2006), and will try to refine those variables using our case study analysis.

The first category comprises the political variables, which, despite their apparent relevance for both emigrant and non-emigrant voters, could

[END PAGE 116]

not be measured in the case of Mexico. Indeed, as the Mexican legisla- tor decided to prohibit political campaigns abroad, the effect of political spending could not be measured. Similarly, the effect of political frag- mentation (i.e. the effect of having a smaller or larger number of parties involved in the campaign) also could not be accounted for. The close- ness of the election, a variable that postulates that closer elections draw major turnout, could be analysed in the case of Mexico, where the 2006 Presidential election was decided by less than a 250,000-vote difference. If we look at the effect of the expected close election on the registration process that took place several months before the election, low results lead to discarding that variable and, instead, looking at others such as bureaucratic barriers. However, if we look at the rate of actual participation among those who managed to register, we observe that 81 per cent of registered voters abroad returned their ballot by mail on time. Two elements may explain this data: First, it could be argued that those who made the effort to register through this complex procedure will make sure that they eventually vote and do not abstain. Second, the hypothesis that registered voters were encouraged to return their ballot by the desire to make a difference in the close election.

The second category covers the institutional variables, which we were partially able to test in the Mexican case. The literature on voter turn- out has identified that the electoral system (i.e. the mode of attribution of seats) has demonstrated the influence of proportional systems on turnout. In the case of Mexico, the fact that the right to vote is limited to Presidential elections makes this variable non-applicable. Yet, looking at other cases, such as Italy, where emigrants are invited to vote at both referenda and legislative elections, 3 allows us to point out the role of the electoral system and of the type of election as a relevant variable in the case of external voting. By 
allowing emigrants to vote for their own senators and MP's elected in a foreign constituency (a system that some Mexican migrant lobbyists asked for), Italy brakes apart from more traditional systems in which emigrant votes are mixed to resident votes for the attribution of seats. The potential consequences this has on the electoral campaign abroad (i.e., candidates living abroad are campaign- ing among emigrants) and on the migrant's sense of being represented in the home country supports the idea that the electoral system is a rele- vant variable to explain turnout abroad. The Italian case also shows the importance of the type of election in which migrants are invited to par- ticipate. Indeed, lower level of emigrant turnout is usually observed in referenda compared to that of legislative elections.

[END PAGE 117]

CHART 1 AGE DISTRIBUTION OF THE EMIGRANT VOTING POPULATION9

\section{CHART 1}

AGE DISTRIBUTION OF THE EMIGRANT VOTING POPULATION ${ }^{9}$

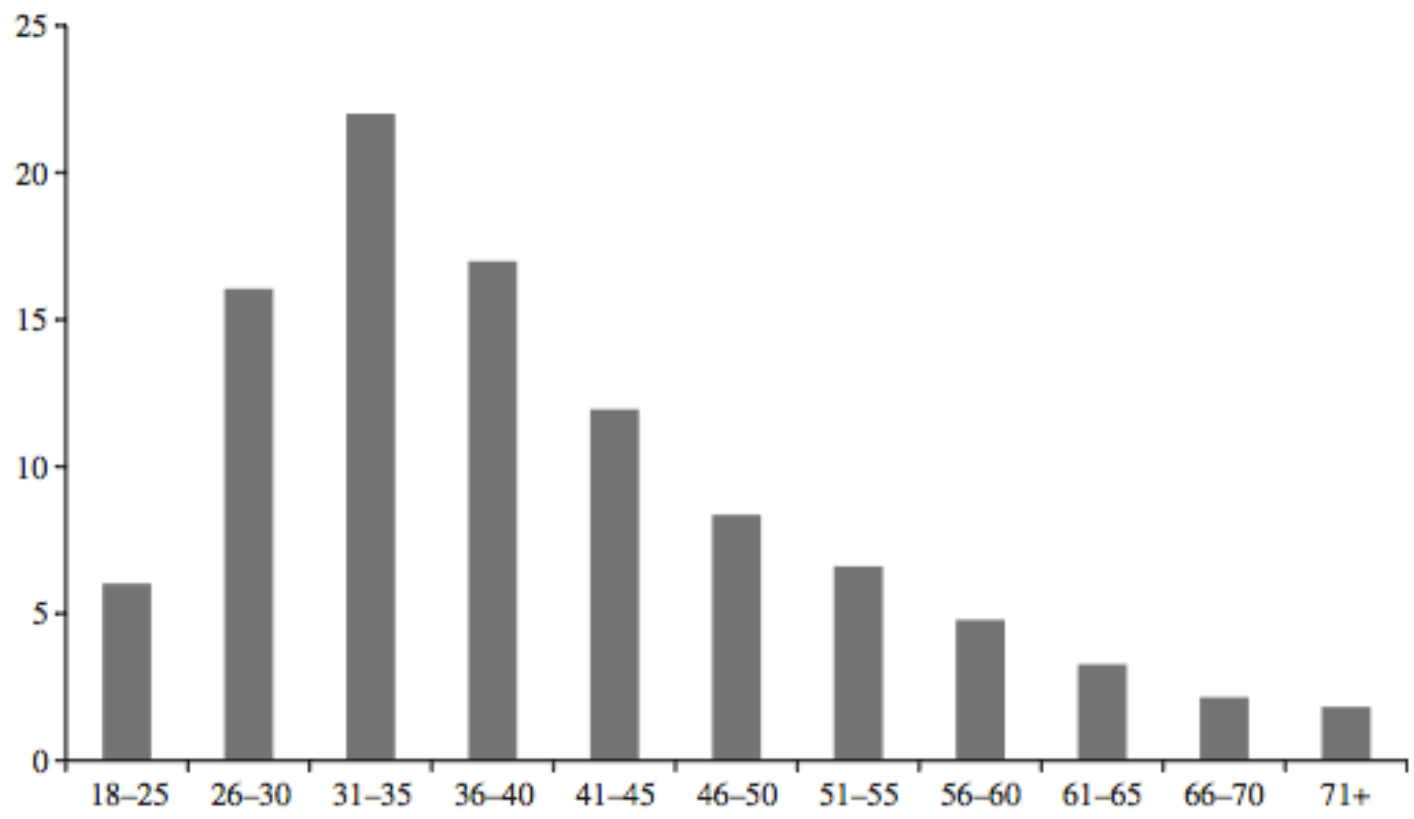

The most decisive institutional variable that we have stressed in the Mexican case, however, is the registration requirements. As we have seen, the restrictive legislation adopted as a result of political compromise has established various bureaucratic barriers and has provided limited resources to organize elections abroad. Even though we showed how this greatly affected the registration process and turnout, bureaucratic barriers do not suffice to explain the extremely limited participation of Mexicans abroad. For this reason, we also pointed out other kinds of variables.

These variables belong to the third category of variables that are of demographic and socioeconomic nature. Despite the fact that our anal- ysis did not focus on these variables, demographic characteristics, such as age and gender, frequently used in the general turnout literature also applies to the analysis of turnout abroad. In the case of Mexico, we find that gender distribution of Mexican voters in the United States (42.46\% women and $57.54 \%$ were men) corresponded closely to gender distribu- tion among Mexican migrants in the United States as a whole. Similarly, age distribution is consistent among voters versus the overall Mexican migrant population in the United States (see Chart 1).4 Indeed, 87.99 per cent of all voters belong to the 18-55 years old or younger age cate- gory, which also corresponds to 78.4 per cent of the Mexican population in the United States (Migration Policy Insitute, 2010, COVE, 2006). We 
believe the domination of younger voters $(61.07 \%$ of voters are between

[END PAGE 118]

18 and 40 years old) should be examined in relation to other demo-

graphic variables that are particular to emigrant voters.

In addition to these variables, the length of stay in the country of resi- dence should also be taken into account in future studies in order to continue our scope of discussion of emigrants' interest in home country elections; we can analyse if time abroad impacts turnout. Also, the legal status of emigrants in the country of residence is relevant as a further variable, which, as we have seen in Mexico, has prevented potential vot- ers from getting a voter identity card. By comparing the low registration to vote from abroad with the massive mobilization to get the consular ID card, we also hypothesized that the legal status may decrease the importance of home country politics compared to the benefit of other issues that have more direct consequences on the migrant's daily life.

With our discussion of Mexicans in Switzerland, we also demonstrated how the place of residence may impact turnout, considering its influence on the authorities and the associations' capacity to reach emigrants. Lastly, income, occupation and, particularly, education of emigrants were also highlighted as relevant elements to take into account. Since both obtaining and filling in the form required basic literacy, and return- ing it implied a cost, all these variables may have been at play in differ- ent proportions in considering the Mexican case.

Our analysis of the immigrant turnout in host country elections has also led us to focus on trust in home country elections as a factor of influ- encing turnout. While we saw that trust has been a decisive element in mobilizing migrants to lobby for external voting, the effect of trust on voter

turnout abroad could not be precisely measured in the 2006 Presi- dential Election in Mexico. Yet, as we have illustrated above, several migrant associations have had the impression that the Mexican State has purposefully not made it possible for large number of migrants to register. This could undermine their trust in the State with further nega- tive impacts on turnouts in future elections.

As a matter of concluding this paper, we have seen that neither bureau- cratic barriers nor migrants' lack of interest in home country elections are sufficient enough variables to explain low turnout, but that an addi- tional variety of factors should be taken in consideration. These variables will be useful in the analysis of future Mexican elections, but also in the analysis of other countries' experiences of external voting as well. To conclude, we would, however, like to question the idea that

[END PAGE 119]

Mexico's first experiment of external voting is considered a failure by looking beyond simply turnout. The strict legislation adopted by the Mexican Congress and its rigorous application by the IFE has rendered the elections abroad extremely reliable in terms of procedure. This situ- ation should not be underestimated if we compare it to that of the national territory where electoral disputes have paralysed the country for weeks. None of the accusations of fraud made during that period concerned the votes that were cast abroad. Also, the prohibition of political parties to campaign abroad and the limited influence of migrant associations on migrants' decisions to register seem to confirm that voting from abroad has been an individual decision rather than a response to social obligations that the Mexican corporatist model of politics has often promoted. Beyond limited voter turnout, Mexico's first experience has thus demonstrated the reliability of the system over- all, and the maturity of voters abroad - two elements that could ensure the longevity and, possibly, the liberalization of Mexico's legislation on external voting in the future.

\section{NOTES}

1. This figure includes a large share (around 3 million) of persons under 18 years old who do not qualify as voters.

2. This study also presented a bias since it focused on emigrants holding a voter identity card and crossing the border on the day of the election to cast their vote (therefore excluding undocumented emigrants from the elec- toral body).

3. Under a different legislation, Italians abroad can also participate in Euro- pean Parliamentary Elections 
and vote for Italian candidates from abroad.

4. However, it should be mentioned that the COVE data on age distribution does not differentiate between countries. This means that this data includes the 5000 voters who live outside of the United States.

5. Source: COVE, 2006 and IME, 2010. 6. Source: COVE, 2006. 7. Source: COVE, 2006 and Cornelius, et al., 2007. 8. Source: Migration Policy Insitute, 2010 and COVE, 2006. 9. Source: COVE, 2006.

\section{REFERENCES}

Barry, K. 2006 "Home and away: the construction of citizenship in an emigration context", New York University Law Review, 81(1): 11-59.

[END PAGE 120]

Baubo" ck, R. 2007 "Stakeholder citizenship and transnational political participation:

a normative evaluation of external voting", Fordham Law Review, 75(5): 2393-2447. Berger, M., et al.

2004 "Political integration by a detour? ethnic communities and social capital of migrants in Berlin", Journal of Ethnic and Migration Studies, 30(3): 491-507.

Bevelander, P., and R. Pendakur 2009 "Social capital and voting participation of immigrants and minori-

ties in Canada", Ethnic and Racial Studies, 32(8): 1406-1430. Caldero' n Chelius, L.

2003 Votar en la distancia, Instituto Mora and Coordinacion General para la atencion al migrante

Michoacano, Mexico.

2007 "Algunas coordenadas de analisis para comprender el voto en el exterior de 2006", in J.

Peschard (Ed.), 2 de Julio, Reflexiones y Alternativas, UNAM, Mexico.

2010 Los Superhe' roes No Existen, Instituto Mora, Mé xico. Collyer, M., and Z. Vathi

2007 "Patterns of extra-territorial voting", Development Research Cen- tre on Migration, Globalisation

and Poverty Working Paper, Sussex Center for Migration Research, Brighton.

Cove 2006 Informe Final Sobre el Voto en el Extranjero, IFE, Mexico City.

Desipio, L. 1996 "Making citizens or good citizens? Naturalization as a predictor

of organizational and electoral behavior among Latino immi-

grants", Hispanic Journal of Behavioral Sciences, 18(2): 194-213. Escobar, C.

2007 "Extraterritorial political rights and dual citizenship in Latin America", Latin American Research

Review, 42(3): 43-75.

Espinoza Valle, V.A. 2004 El voto lejano : cultura polití ca y migración n Mé xico-Estado Unidos,

Colegio de la Frontera Norte, Mexico. Fennema, M., and J. Tillie

1999 "Political participation and political trust in Amsterdam: civic communities and ethnic networks", Journal of Ethnic and Migra- tion Studies, 25(4): 703-726.

Geys, B. 2006 "Explaining voter turnout: a review of aggregate-level research", Electoral Studies, 25(4): 637-663.

Idea 2007 Voting from Abroad. The International IDEA Handbook, Inter-

national Institute for Democracy and Electoral Assistance, and The Federal Electoral Institute of

Mexico, Stockholm and Mexico.

[END PAGE 121]

IFE 2005

IME 2010

Opinió n Té cnica del IFE Sobre la Modalidad del Voto Postal, IFE, Mexico City.

Mexicanos Residentes en el Mundo 2009, Segretaria de Relaciones

Exteriores, Mexico City. Itzigsohn, J.

2000 'Immigration and the boundaries of citizenship: the institutions of immigrants' political

transnationalism", International Migration Review, 34(4): 1126-54.

Jacobs, D., K. Phalet, and M. Swyngedouw $2004 \quad$ "Associational membership and political

involvement among eth-

nic minority groups in Brussels", Journal of Ethnic and Migration

Studies, 30(3): 543-559. Lafleur, J.-M.

2009 'L'extension des droits politiques aux citoyens vivant a' l'exte' rieur du territoire national a' l'e 're

de la migration transnationale", RSCAS working papers, (28): 1-29.

forthcoming "Why do states enfranchise citizens abroad?: Comparative Insights from Mexico, Italy 
and Belgium", Global Net-

works. Levitt, P., and R. De La Dehesa

2003 "Transnational migration and the redefinition of the state: varia- tions and explanations", Ethnic and Racial Studies, 26(4): 587-611.

Lo' pez-Guerra, C. 2005 "Should expatriates vote?" The Journal of Political Philosophy,

13(2): 216-234. Marcelli, E.A., and W.A. Cornelius

2005 "Immigrant voting in home-country elections: potential conse- quences of extending the

franchise to expatriate Mexicans residing in the United States", Mexican Studies/Estudios Mexicanos, 21(3): 429-460.

Martí nez Saldañ a, J. 1998 "In Search of our lost citizenship: Mexican immigrants, the right to vote, and the transition to democracy in Mexico", L'Ordinaire

Latino-Amé ricain, (173-174): 153-166. McCann, J., W.A. Cornelius, and D. Leal

2006 Mexico's 2006 Voto Remoto and the Potential for Transnational Civic Engagement among Mexican Expatriates, American Political Science Association, Philadelphia.

Migration Policy Insitute $2010 \quad$ Mexican Immigrants in the United States, MPI, Washington, DC.

Moctezuma Longoria, M. 2003 "La voz de los actores. Ley migrante y Zacatecas”, Migració n y

Desarrollo, (1): 100-118.

[END PAGE 122]

Nohlen, D., and F. Grotz 2000 "External voting: legal framework and overview of electoral legislation", Boletí n Mexicano de Derecho Comparado, 33(99) Portes, A., C. Escobar, and A.W. Radford 2007 "Immigrant transnational organizations and development: a com- parative study", International Migration Review, 41(1): 242-281.

Rhodes, S., and A. Harutyunyan 2010 "Extending citizenship to emigrants: democratic contestation and

a new global norm", International Political Science Review, forth-

coming. Ross Pineda, R.

2005 "La lucha por el voto unio a los Mexicanos", Mx Sinfronteras, 21: 20-22.

Rubio-Marí n, R. 2006 "Transnational politics and the democratic nation-state: norma-

tive challenges of expatriate voting and nationality retention of

emigrants", New York University Law Review, 81(1): 117-147. Smith, R.C.

2008 "Contradictions of diasporic institutionalization in Mexican poli- tics: the 2006 migrant vote and other measures of inclusion", Eth- nic and Racial Studies, 31(4): 708-741.

Spiro, P.J. $2006 \quad$ "Perfecting political diaspora", New York University Law Review, 81(1): 207-233. Suro, R., and G. Escobar

2006 Survey of Mexicans Living in the U.S. on Absentee Voting in Mexi- can Elections, Pew Hispanic Center, Washington, DC.

Togeby, L. $2004 \quad$ "It depends...how organisational participation affects political participation and social trust among second-generation immigrants in

Denmark", Journal of Ethnic and Migration Studies, 30(3): 509-528. Tuckel, P., and R. Maisel 1994 "Voter turnout among European immigrants to the United States", Journal of Interdisciplinary History, 24(3): 407-430.

Turner, S. 2008 "The waxing and waning of the political field in Burundi and its diaspora", Ethnic and Racial Studies, 31(4): 742-765. Waldinger, R.

2008 A Limited Engagement: Mexico and its Diaspora, Migration Study Group at UCLA, Los Angeles. 2009 Homeland Calling? Political and Social Connectivity across Bor- ders, Selected Works, http://works.bepress.com/roger_waldinger/ 36.

Waterbury, M.A. 2010 "Bridging the divide: towards a comparative framework for under-

standing kin-state and migrant sending-state diaspora politics", in

[END PAGE 123]

R. Baubo" ck and T. Faist (Eds), Diaspora and Transnationalism. Conceptual, Theoretical and Methodological Challenges, Amster- dam University Press, Amsterdam, 131-148.

Wucker, M. 2004 "The perpetual migration machine and political power", World

Policy Journal, $21(3)$ : 41-49. 